\title{
ANTHROPOGENIC ACTIVITIES THREATENING THE MANAGEMENT OF ECOTOURISM RESOURCES IN OLD OYO NATIONAL PARK, NIGERIA Oladeji. S.0., ${ }^{1}$ Agbelusi, E.A. ${ }^{1}$ and Trevelyan, R. ${ }^{2}$
}

\author{
DOI: http://dx.doi.org/10.4314/ejesm.v5i1.12
}

Received $22^{\text {nd }}$ November 2011; accepted $17^{\text {th }}$ February 2012

\begin{abstract}
Abundant fauna and flora resources in Nigeria are being threatened due to the increasing rate of anthropogenic activities across the protected areas in the country. This study examined anthropogenic activities threatening the natural resources considered to be of ecotourism value in Old Oyo National Park. Primary data were collected through administration of a set of questionnaire on the respondents. Data collected were analyzed using descriptive statistics. Result of the analysis showed that human activities had negative impacts on the Park resources. Recommendations were made on the need to engage in aggressive afforestation, conservation education and provision of fund to support sustainable livelihood practices.
\end{abstract}

Keywords: natural resources, anthropogenic, sustainable livelihood, ecotourism, impacts, National Park

\section{Introduction}

Tropical forests were reported to be under threat from large scale forest clearance, mineral extraction and industrialization. Around 20.4 million hectares of tropical forest are being destroyed or seriously damaged each year in areas such as Amazonia, Central America, Malaysia, Indonesia and Borneo (Boo, 1990). In Africa, the loss of Savanna woodlands is now a cause of great concern. The consequences of forest destruction are numerous with the loss of biodiversity as possibly the most important. Between 1990 and 2000 Africa lost52million hectares of forest, this amount to a decrease of 0.8 percent per year and 56 percent of the global total. It is estimated that $60 \%$ of the tropical forest areas cleared in Africa as whole between these periods were converted to permanent agriculture small holdings (UNEP, 2010). Biodiversity, therefore is being exploited at much faster rate than ever before with negative implication for sustainable human livelihood (Turner et.al.1990) Consequently, understanding the effects of forest clearance on wildlife and wildlife populations, as well as devising strategies to ameliorate these effects, is an increasing challenge for resource managers. Given the conflicting mandate to both encourage human use and to protect sensitive natural resources in national parks, developing reliable strategies for assessing and monitoring the effects of human activities on natural resources is essential to ensuring appropriate stewardship of these resources. According to Honey, 1999 in reaction to Elephant and Rhino poaching in East Africa in the early 90s the only way to protect these and other wildlife species was Scientist and Park officials to give those living near the National Parks a financial incentive in the parks, wildlife conservation and tourism.

World Tourism Organisation 2002 report suggests that ecotourists have preference for wildlife viewing in protected areas, viewing rare species, visiting indigenous people and bird watching. The increasing rate of anthropogenic activities in and around the protected areas across the world has negative impacts on such wildlife, and thus potentially deterring interested ecotourists from visiting such sites. The resultant effect of this menace is huge lost in revenue accruable to the management of such destinations as well as other economic benefits that could be derivable by the host communities due to reduction in tourist patronage. These also could have serious negative impact on the economy of such countries. According to Holden, 2003 tourism or ecotourism has become one of the economic sectors that generate substantial income and maintains

\footnotetext{
${ }^{1}$ Department of Ecotourism and Wildlife Management, Federal University of Technology, Akure

${ }^{2}$ Department of Zoology, Cambridge, United Kingdom Corresponding author email:Oladejisunny@yahoo.com
} 


\section{Data Collection}

The Primary data were collected through administration of sixty two questionnaires to the staff in the Park Protection and Conservation Department. This includes forty questionnaires administered to the rangers assigned to the five administrative /management range/Unit, six questionnaires were administered to staff in Conservation Education and Public Enlightenment Unit, six questionnaires were administered to the staff at Litigation and Prosecution Unit, six to those in Interpretation and Museum Unit and four to the staff in Research Unit. Focus Group Discussions were held with those engaged in logging/charcoal/firewood selling/producers, hunter's group and the fishermen in the selected Local Government areas adjoining the Park. The secondary data collected from the head office of the park in Oyo include record of arrest and prosecution since inception of the park.

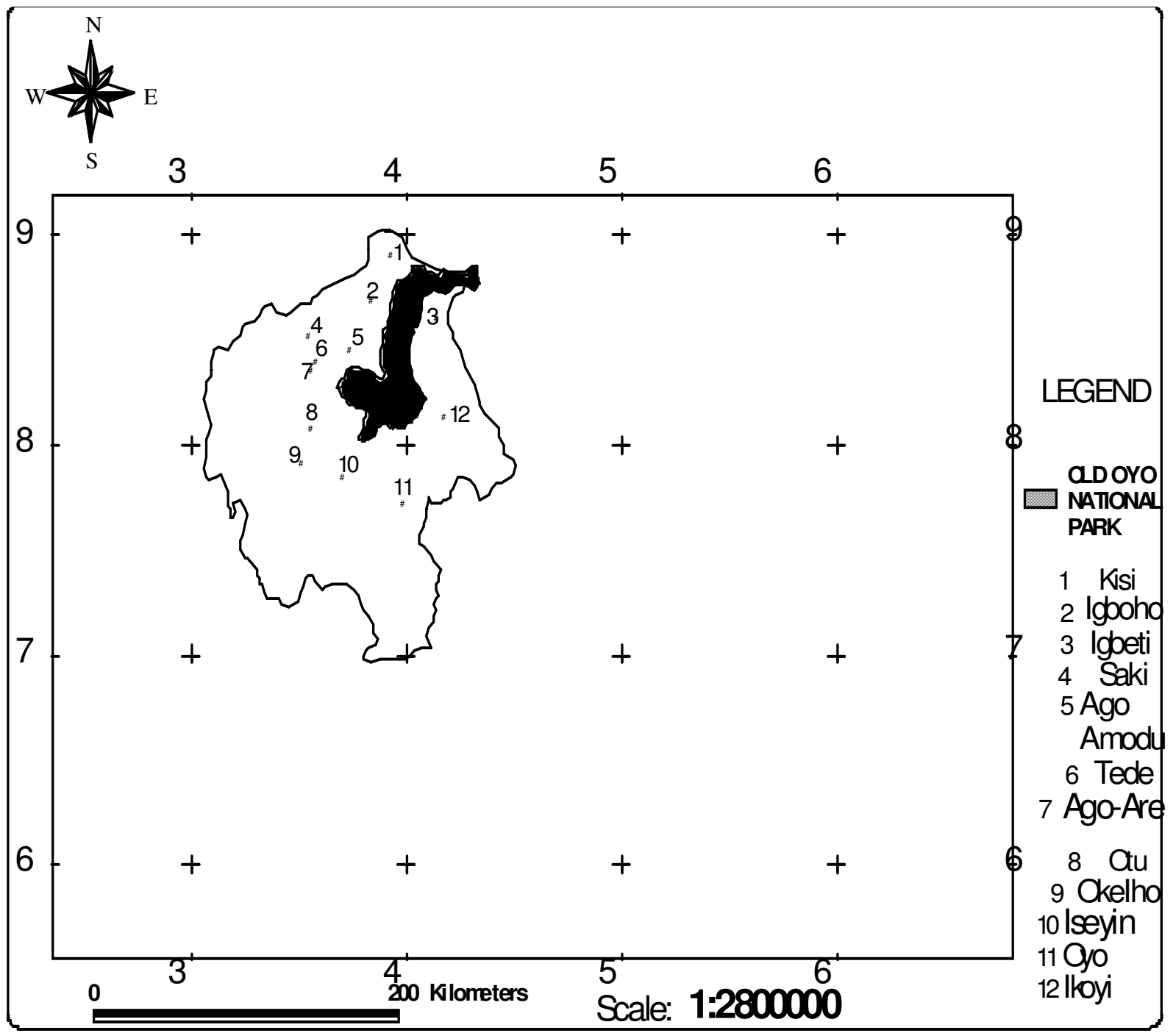

Fig: 1 Map of Oyo State showing location of Old Oyo National Park and adjoining community 


\section{Illegal Activities ever recorded since the inception of the Park}

Table 2 Record of prosecution of offences from 1993-2009.

\begin{tabular}{|c|c|c|c|c|c|c|c|c|c|c|c|c|c|c|c|}
\hline \multirow[b]{2}{*}{ S/No } & \multirow[b]{2}{*}{ Year } & \multicolumn{9}{|c|}{ COURT VERDICT } & \multicolumn{3}{|c|}{ COMPOUNDMENT } & \multirow[b]{2}{*}{ Total } & \multirow[b]{2}{*}{$\begin{array}{l}\text { Fine/compo } \\
\text { undment } \\
\text { paid }(\mathrm{N})\end{array}$} \\
\hline & & Fined & Jailed & $\begin{array}{l}\text { Dischar } \\
\text { ged \& } \\
\text { Acquitte } \\
\text { d }\end{array}$ & $\begin{array}{l}\text { Warne } \\
\mathrm{d} \& \\
\text { Discha } \\
\text { rged }\end{array}$ & $\begin{array}{l}\text { Baile } \\
\text { d }\end{array}$ & $\begin{array}{l}\text { Pendi } \\
\text { ng }\end{array}$ & $\begin{array}{l}\text { Yet to } \\
\text { be } \\
\text { determi } \\
\text { ned }\end{array}$ & Died & $\begin{array}{l}\text { At } \\
\text { large }\end{array}$ & Penalized & $\begin{array}{l}\text { Warned } \\
\& \\
\text { discharge } \\
\text { d }\end{array}$ & $\begin{array}{l}\text { Handed } \\
\text { over to } \\
\text { NDLEA }\end{array}$ & & \\
\hline 1 & 1993 & 14 & & & & & & & & & & & & 14 & $5,100.00$ \\
\hline 2 & 1994 & & & & & & & & & & & & & 35 & $15,450.00$ \\
\hline 3 & 1995 & 84 & 2 & 8 & 1 & & & & & & & & & 95 & $67,300.00$ \\
\hline 4 & 1996 & 17 & 3 & & & & & & & & & & & 20 & $12,350.00$ \\
\hline 5 & 1997 & 45 & & 3 & & & & & & & & & & 48 & $69,950.00$ \\
\hline 6 & 1998 & 52 & 1 & 2 & & & & & & & & & & 55 & $65,600.00$ \\
\hline 7 & 1999 & 27 & 10 & 3 & & & & & & & & & & 41 & $36,600.00$ \\
\hline 8 & 2000 & 43 & 46 & 7 & & & & & & & & & & 96 & $79,400.00$ \\
\hline 9 & 2001 & 27 & 7 & 7 & & & & 5 & & & & & & 46 & $189,700.00$ \\
\hline 10 & 2002 & 43 & 22 & 1 & & & & 5 & & & & & & 71 & $692,000.00$ \\
\hline 11 & 2003 & 11 & 4 & 4 & & 2 & & 17 & & & & & & 38 & $130,000.00$ \\
\hline 12 & 2004 & 3 & 24 & 8 & & & 13 & & & & & & & 48 & $297,500.00$ \\
\hline 13 & 2005 & 18 & 68 & 22 & & & 4 & 5 & 1 & 1 & & & 3 & 122 & $179,000.00$ \\
\hline 14 & 2006 & 6 & 34 & 9 & & & & & & & 45 & 3 & 6 & 103 & $862,000.00$ \\
\hline 15 & 2007 & 3 & 1 & & & & & & & & 90 & 2 & & 96 & $\begin{array}{l}2,132,500.0 \\
0\end{array}$ \\
\hline 16 & 2008 & 3 & 3 & 1 & & & & & & & 149 & 2 & & 158 & $\begin{array}{l}4,834,450.0 \\
0\end{array}$ \\
\hline 17 & 2009 & 20 & 33 & 6 & 0 & 0 & 0 & 0 & 0 & 0 & 113 & 0 & 0 & 117 & \\
\hline \multicolumn{2}{|c|}{ Grand total } & 400 & 225 & 76 & 1 & 2 & 17 & 32 & 1 & 1 & 397 & 7 & 9 & 1203 & \\
\hline
\end{tabular}

Source: Old Oyo National Park Office in Oyo 
Table 4 Illegal activities recorded as obtained through administered questionnaires.

\begin{tabular}{lll}
\hline ILLEGAL ACTIVITIES & FREQUENCY & PERCENTAGE \\
EVER RECORDED & & \\
\hline Grazing & 45 & 32 \\
Hunting & 38 & 28 \\
Fishing & 18 & 13 \\
Mining & 05 & 3.6 \\
Honey tapping /NTFP & 06 & 4.3 \\
Logging & 25 & 18.2 \\
\hline Total ** & 137 & 100 \\
\hline
\end{tabular}

Multiple response **

The most frequent illegal activities were grazing and hunting followed by logging and fishing (Table 4). Rangers in Oyo-Ile range (Igbeti) indicated grazing as the most common illegal activity being experienced in their range compared with all other acts. This was followed by hunting and mining operations. The same thing is applicable to Sepeteri range (Igboho) and Marguba range (Sepeteri) except that mining was not mentioned but rather logging /firewood/ charcoal collections. Fishing and hunting constitutes the highest percentage of illegal activities being recorded in Tede range (Tede) and Ikoyi range coupled with logging especially along the water bodies in these ranges. . Honey tapping was not as pronounced as other form of illegal activities.

Reasons for the Increase during the dry season

Table 5: Reasons for the increase of illegal activities being recorded in the Park

\begin{tabular}{lllll}
\hline REASON & FOR & THE & FREQUENCY & PERCENTAGE
\end{tabular}

INCREASE

\begin{tabular}{lll}
\hline Visibility of animals & 43 & 34.1 \\
Accessibility & 30 & 23.8 \\
Joblessness & 18 & 14.3 \\
Availability of animals & 14 & 11.1 \\
Availability of grasses or flush & 14 & 11.1 \\
Poverty & 05 & 4.0 \\
No response & 02 & 1.5 \\
\hline Total ** & 126 & 100 \\
\hline
\end{tabular}

Multiple response **

Increasing rate of illegal activities were said to be observed by $93.5 \%$ of the respondents during the dry season due to visibility, accessibility and joblessness due to low farming activities during 


\section{Focus Group Discussion}

The Focus Group Discussion ( FGD) with the hunters group revealed a number of animals that were hunted were Civet cat, Genet cat, Hunting dog, Bush buck, Kob, Roan antelope, Western harte beest, Red flanked duiker, Buffalo, Water buck, Oribi, Baboon, Monkey, Hare and Grasscutter. The names of instruments used for hunting were Dane guns, traps, headlamp, sword, hoes and cutlasses. Hunting expedition is mostly carried out at night to avoid being sighted by the Park Patrol Team (PPT) or the assigned rangers and other diurnal animals. This usually involved both the youth and adult in the age range of 18-25years and 26-55years respectively.

The FGD with the charcoal / firewood sellers or producers revealed that three major species of trees were preferred. These were Anogeissus leiocarpus, Afzelia africana and Vitellaria paradoxum. Clear felling of the trees was the usual harvesting practice and the method of production was observed to be very crude, (Heaps of firewood covered with sand, leaves and set on fire was sighted at open space nearby ). One major reason given for the production and the use of the charcoal was because it was found to be cheaper than other source of energy in the localities.

Tilapia spp, Malapterus electricus, Parachina obscura, Lates niloticus, Murmurs rume, Synodontis spp were mentioned by the fishermen. Fishing practices like the use of chemicals, crude fishing tools e.g. gears with smaller mesh size, late fishing throughout the day, Interception of the species of fish like Murmurs rume in the course of egg laying down stream as a result of increase in the volume of the water bodies upstream and arrest of illegal fishermen by the Park management were reported. Sizes of Tilapia species that were reported being caught were reducing unlike before when larger sizes were recorded.

\section{Discussion}

Grazing was the predominant anthropogenic activity in Old Oyo National Park. Adeola, (1995) reported a similar result and that this was being perpetuated by the Bororos, Sokoto Hausa Fulani, Ilorin Yoruba
Fulanis and the Bokolos. Hunting activity was recorded across the park. These activities were frequently reported in dry season when the Park is easily accessible and visibility was very high. The level of hunting observed may be responsible for the fact that many animals observed in the park in the past such as Elephant, Leopard and Lion (Petridges, 1965, Ayodele, 1987, Afolayan, and 1997) are no longer there (Alarape,2002) and were not sighted in this research work. Recent surveys by the Park staff revealed that the fauna population in the Park were declining (Falade, 1993).Effects of anthropogenic activities are typically of short duration; cumulatively they can affect wildlife distributions and populations adversely in both the short- and long-term (Burger1981; Henson and Grant 1991; Fernandez and Azkona 1993; Holmes et al., 1994; Steidl and Anthony 1996, 2000; Swarthout and Steidl 2001, 2003; Mann et al., 2002; Johnson et al., 2005).

The fishing community near the park use chemicals as well as crude fishing gear and it appears there is uncontrolled fishing throughout the day and night. The temporal restrictions placed by the management of the Park such as fishing bans on Sunday in water bodies around the Park has been abolished due to increasing pressures from the fishermen. The fact that the fishermen use small mesh sizes and that they believe that fish species such as Tilapia are decreasing in size suggests that fishing practices being adopted may be unsustainable. The Park management in combating these increasing menaces has organized what the Staff described as Park Patrol Team on daily and mostly monthly basis to arrest poachers. This effort is commendable although other measures still need to be put in place. This was the view of the world's protected areas managers at the IV Global Congress on National Parks and protected areas in Caracas, 1992. It was agreed that rather than concentrating all conservation efforts on fighting poachers or other illegal activities as the case may be it would be better to encourage sustainable development projects for the rural communities around protected areas so that the need to poach was removed but to develop 


\section{References}

Adeola M. O. (1995). Effect of illegal grazing on the ecosystem of Old Oyo National Park In: Impact of human activities on the West African Savana .Proceedings of the Regional Training workshop held at the Federal University of Technology, Akure, (ed) Afolayan, Agbelusi and Akindele, $23^{\text {rd }}-25^{\text {th }}$, July, 1995 pp 93-96

Adrian P. (1994). Protected Areas, (All of Us) 13, Environmental Education Dossiers, International Union for Conservation of Nature and Natural Resources (IUCN)

Afolayan, T.A., Agbelusi, E.A.,Ayodele, I.A, Balogun, A.M, Ogunmodede, M.S (1997). Management Plan of Old Oyo National Park pp 215.

Alarape. A. (2002). Culture and Conservation in and around Old Oyo National Park. Unpublished $\mathrm{PhD}$ Thesis Submitted to the Department of Wildlife and Fisheries, University of Ibadan.

Ayodele A.I. (1987). Ecological basis for the management of Old Oyo National Park Ph.D Thesis submitted to the Department of Wildlife and Fisheries, University of Ibadan.

Boo, E. (1990): Ecotourism: Potentials and pitfalls, World Wild Fund for Nature (WWF) Washington,D.C

Burger, J. 1981. The effect of human activity on birds at a coastal bay. Biological Conservation 21, 231-241.

Falade, G. O. (1993). Socio-Economic Evaluation of Wildlife Based Tourism Development. In selected Conservation Areas in Nigeria (Unpublished $\mathrm{PhD}$ Thesis), submitted to the Department of Wildlife and Fisheries, University of Ibadan, Ibadan, Nigeria.

Fernandez, C. and Azkona, P. (1993). Human disturbance affects parental car of marsh harriers and nutritional status of nestlings. Journal of Wildlife Management 57, 602-608. Gubbi, S. (2003). Wildlife on the run. www.wildlifefirst.info/images/wordfiles/onther un.doc

Henson, P., and T.A. Grant. (1991). The effects of human disturbance on trumpeter swan breeding behavior. Wildlife Society Bulletin 19, 248-257.
Holden,A.(2003).Environment and Tourism, $1^{\text {st }}$ ed, Routledge, England pp.5,62,64,68,88,97,165

Holmes, T.L., R.L. Knight, L. Stegall, and G.R. Craig. (1994). Responses of wintering grassland raptors to human disturbance. Wildlife Society Bulletin 21, 461-468

Honey, Martha S.Honey., 1999. Treading lightly? Ecotourism's impact on the environment .November 15, 2006.www.findarticles.com

IUCN (2000). 2000 IUCN Red List of Threatened Species IUCN, Gland, Switzerland .xviii+61

Johnson, C.J., M.S. Boyce, R.L. Case, H.D. Cliff, R.J. Gau, A. Gunn, and R. Mulders. (2005. Cumulative effects of human developments on arctic wildlife. Wildlife Monographs 160.

Steidl, R.J., and R.G. Anthony. (1996). Responses of bald eagles to human activity during the summer in interior Alaska. Ecological Applications 6, 482-491.

Swarthout, E., and R.J. Steidl. (2001). Flush responses of Mexican spotted owls to recreationists. Journal of Wildlife Management 65, 312-317.

Mann, S.L., R.J. Steidl, and V.M. Dalton. (2002). Effects of cave tours on breeding cave myotis. Journal of Wildlife Management 66 , 618-624.

Nigeria National Park Service (2000). Information Brochure. Premier Concepts Limited, Borno State, Nigeria

Oladeji, S. O, Afolayan, T. A and Agbelusi E, A (2011). Survey of Ecotourism potentials of Old Oyo National Park. ROAN The journal of Conservation Vol.5 180-190

Petridges, G. A. (1965). Advisory report on wildlife and National Park in Nigeria (1962). Special Publication No.8 of American Committee for International Projection, Bronx, New York, 1965

Theodros Atlabchew. (2002).Sustainable Tourism Development. Paper presented on the tourism Symposium Occasion of the World Tourism Day, Sheraton Addis, September 24 Turner B.L., Clark W.C., Kates, R.W., Richards J.F., Mattews J.T, and Meyers W.B. (ed.) (1990). The earth as transformed by 